\title{
Model terapi kognitif sebagai upaya peningkatan kualitas hidup pada pasien dengan penyakit kronis: Literature review
}

\author{
Yayan Kurniawan ${ }^{1 *}$, Untung Sujianto ${ }^{2}$, Mardiyono Mardiyono ${ }^{3}$ \\ 1,2Universitas Diponegoro, Indonesia \\ ${ }^{3}$ Politeknik Kesehatan Kemenkes Semarang, Indonesia \\ *Coresponding Author: yayansewar@gmail.com
}

\begin{abstract}
Abstrak
Pendahuluan: Pada tahun 2015 sekitar 70\% kematian di dunia disebabkan oleh penyakit kronis. Penyakit kronis akan berdampak beragam baik secara biologis, psikologis, sosial, spiritual. Pemberian terapi kognitif mampu menjadi solusi bagi pasien kronis dengan segala kompleksitasnya. Tujuan: Menjelaskan berbagai terapi kognitif untuk meningkatkan kualitas hidup pada pasien dengan penyakit kronis Metode: Data based pencarian meliputi EBSCO, ProQuest, Springer, NCBI dan Scince Direct dengan kata kunci: cognitive therapy, Intervention, Chronic disease dan Quality of Life. Kriteria inklusi: artikel terbitan tahun 2014-2019, full text, bahasa inggris. Desain artikel yang diambil adalah Quasy experimental study dan RCT. Sebanyak 7 artikel yang sesuai kriteria inklusi dilakukan analisis. Hasil: Semua kelompok intervensi menujukan peningkatan kualitas hidup. Simpulan: Intervensi acceptance and commitment therapy, edukasi peer group, edukasi berbasis health belief model, program intervensi bebasis self-care, aerobic physical rehabilitation, yoga, dan hipnoterapi mampu meningkatkan kualitas hidup dan dapat dijadikan alternatif terapi pada pasien dengan penyakit kronis.
\end{abstract}

Kata kunci: Kualitas hidup; intervensi; terapi kognitif; penyakit kronis.

The cognitive therapy model as an effort to enhance quality of life in patients with chronic disease: Literature review

\begin{abstract}
Introduction: In 2015 around 70\% of deaths in the world were caused by chronic diseases. Chronic diseases will have a variety of impacts both biologically, psychologically, socially, spiritually. The provision of cognitive therapy can be a solution for chronic patients with all its complexity. The purposes: Explain various cognitive therapies to improve the quality of life in patients with chronic diseases. Methods: Data based searches include EBSCO, ProQuest, Springer, NCBI and Science Direct with keywords: cognitive therapy, Intervention, Chronic disease and Quality of Life. Inclusion criteria: articles published in 2014-2019, full text, in english. The design articles taken are Quasy experimental study and RCT. A total of 7 articles that fit the inclusion criteria were analyzed. Results: All intervention groups aimed at improved quality of life. Conclusions: Acceptance and commitment therapy interventions, peer-group education, health belief model-based education, self-care-based intervention programs, aerobic physical rehabilitation, yoga and hypnotherapy can improve quality of life and can be used as alternative therapies for patients with chronic diseases.
\end{abstract}

Keywords: Quality of life; interventions; cognitive therapy; chronic diseases

How to Cite: Kurniawan, Y., Sujianto, U., \& Mardiyono, M. (2020). Model terapi kognitif sebagai upaya peningkatan kualitas hidup pada pasien dengan penyakit kronis: Literature review. NURSCOPE: Jurnal Penelitian dan Pemikiran IImiah Keperawatan, 6(1), 47-56

\section{PENDAHULUAN}

Peningkatan status kesehatan masyarakat adalah bagian perwujudan pembangunan nasional yang ditandai dengan peningkatkan pengetahuan, kemauan, dan kemampuan hidup sehat pada masyarakat, kenyataannya masih banyak masyarakat yang masih belum menyadari pentingnya perilaku hidup sehat. Pola hidup yang tidak sehat pada masyarakat terlihat dari semakin meningkatnya 
angka penyakit kronis pada masyarakat tersebut, seperti penyakit jantung, hipertensi, diabetes, dan penyakit degeneratif lainnya. Data WHO (2015) mencatat sekitar 39.5 juta jiwa atau $70 \%$ kematian di dunia disebabkan oleh penyakit kronis dengan empat penyebab kematian terbanyak adalah penyakit jantung, kanker, diabetes, dan PPOK. Penyakit kronis merupakan penyakit dengan ciri bersifat menetap, menyebabkan penurunan kemampuan fisik pada penderitanya dan untuk menyembuhkannya penderita harus melakukan perawatan dalam waktu yang lama (Lubkin \& Larsen, 2006).

Penyakit kronis akan berdampak secara biologis, psikologis, sosial, spiritual. Penelitian menunjukkan bahwa gejala fisik dan tekanan psikologis, secara aktual menjadi masalah pada kualitas hidup pasien (Kousoula Gerasimoula, 2015). Sosiodemograpi, status perkwinan, pekerjaan serta pengetahuan klinis dapat memengaruhi kualitas hidup pasien (Sohaib, 2018). Substansi permasalahan kualitas hidup pada pasien umumnya terdiri dari sejumlah domain termasuk fungsi fisik, kesejahteraan psikologis (kecemasan), depresi, dan masalah dukungan sosial (Sheila Perry, 2007). Pasien yang menjalani terapi pada penykait kronis akan mengalami perubahan yang besar dalam hidupnya, mulai dari kebiasaankebiasaan yang dilakukan hingga pada pembatasan diet tertentu, sehingga hal tersebut memungkinkan akan menggeser perilaku pasien tersebut (Stuart, 2013). Menurut Rahma (2015) menangani dan memberi pengentahuan yang tepat akan sangat menguntungkan pasien, selain penyembuhan secara fisiologis mengubah perilaku dan meningkatkan kesadaran pasien sangat penting agar mencapai kesejahteraan bagi pasien secara holistik.

Terapi kognitif menjadi perhatian penting bagi pelayanan kesehatan maupun pengembangangan ilmu dibidang kesehatan terutama keperawatan hal ini karena berbagai model terapi kognitif telah menunjukan keberhasilan (Vani Rahmasari, 2018). Menurut Endang (2012) terapi non farmakologis memiliki sasaran pada perubahan perilaku, pengambilan keputusan serta menyentuh aspek fisiologis dan psikologis pasien oleh sebab itu berbagai model terapi kognitif direkomendasi sebagai pengobatan pendampingi terapi medis pada berbagai penyakit kronis. Terapi non farmakologis mampu menjadi solusi bagi pasien kronis dengan segala kompleksitasnya.

Studi Literature review ini diharapkan menjadi referensi bagi perawat baik dalam akademisi maupun klinisi dalam pemilihan model terapi non farmakologis yang tepat pada berbagai macam penyakit kronik sebagai upaya peningkatan kualitas hidup pasien, oleh sebab itu berbagai model terapi non farmakologis penting untuk diulas dan dianalisis secara terperinci. Tujuan dari studi literature review ini adalah untuk membahas berbagai terapi non farmakologis sebagai upaya peningkatan kualitas hidup pada pasien dengan penyakit kronik.

\section{METODE}

Metode yang digunakan pada studi ini adalah Literature Review dengan mengunakan pencarian dalam skala besar pada Data based yakni EBSCO, ProQuest, Springer, NCBI dan Science Direct. Beberapa artikel dikolektif berdasarkan topik yang ingin diangkat yakni jenis terapi kognitif yang telah terbukti efektif untuk meningkatkan kualitas hidup pada pasien dengan masalah penyakit kronis yang dirawat di lingkungan klinis. Artikel yang diambil, yaitu dari tahun 2014 sampai 2019, full text, menggunakan bahasa inggris. Kata kunci yang digunakan dalam proses pencarian artikel adalah: Cognitive therapy, Intervention, Chronic disease dan Quality of life. Desain penelitian yang diambil dalam studi ini, yaitu Quasy Experimental Study dan RCT dengan batasan umur partisipan dari 20-70 tahun. Penulis melakukan analisis terhadap artikel yang didapat dan mengambil informasi penting terkait berbagai model terapi kognitif dalam upaya meningkatkan kualitas hidup pada pasien dengan penyakit kronis.

Setelah penulis mencari dan menghilangkan duplikasi, setiap judul artikel yang diambil akan disaring dan diamati sesuai kriteria inklusi. Artikel yang sudah didapatkan dianalisis untuk memastikan artikel tersebut telah sesuai dengan yang diinginkan, oleh sebab itu penulis melakukan peninjauan secara 
langsung dengan cara men-download dan membuka langsung artikel tersebut. Artikel yang telah dinyatakan sesuai selanjutnya akan dianalisis menggunakan PICO (Population, Intervention, Comparing, Outcome) dan dilakukan penilaian menggunakan PRISMA (Preferred Reporting Items for Systematic Reviews and Meta-analysis) tanpa menggunakan meta analisis. Penilaian artikel secara kritis menggunakan CASP (Critical Appraisal Skills Programmed) secara independen. Artikel yang baik (dengan nilai 7-8 poin) dan yang cukup (5-6 poin).

Bagan 1. Diagram strategi pencarian

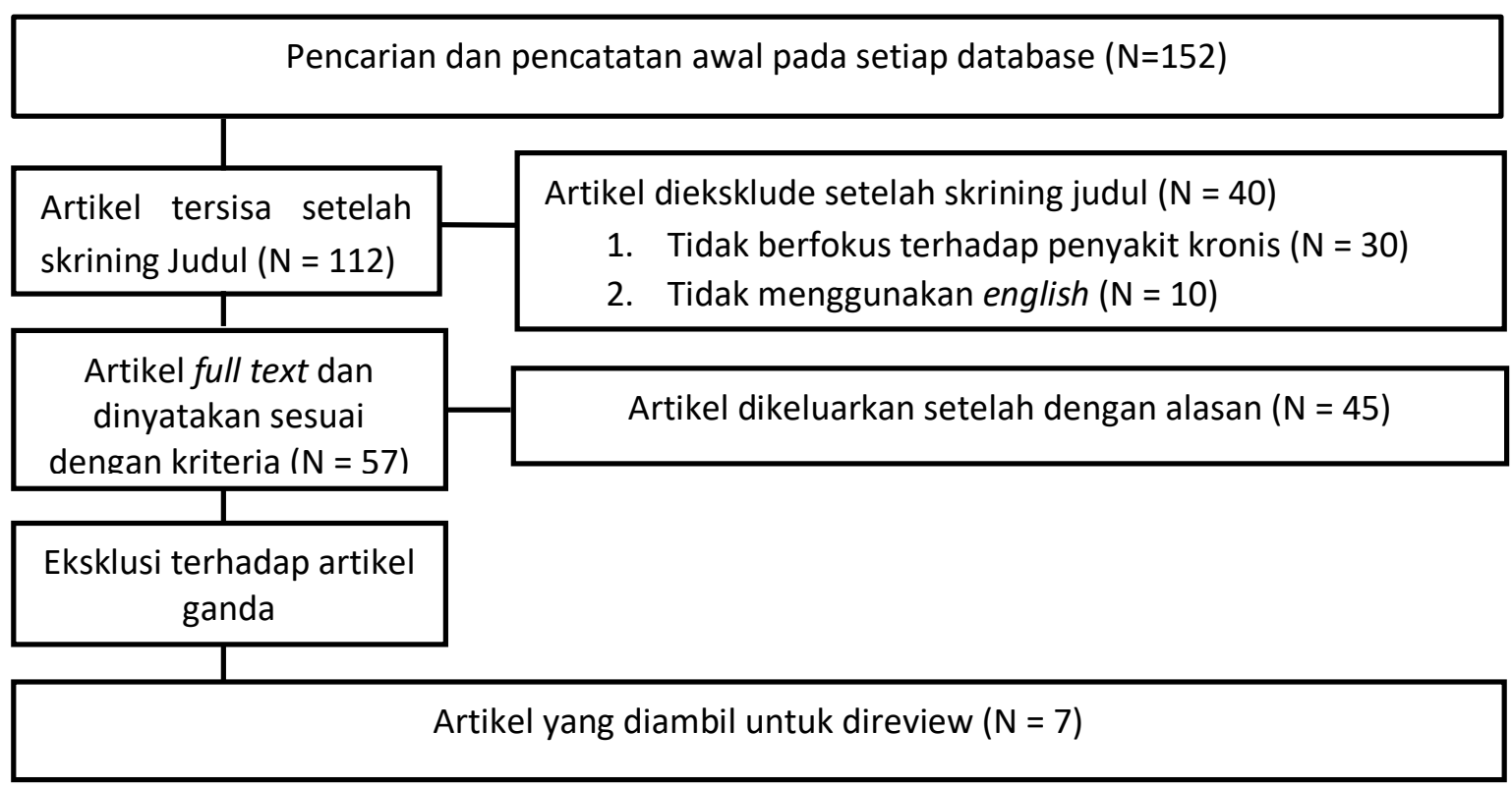

Ekstraksi data yang telah dilakukan yang terdiri dari: total keseluruhan responden, usia, jenis kelamin, protokol intervensi, metode administrasi, hasil serta analitical assessment. Studi ini merupakan studi yang memasukan evidence based study tingkat I, II dan III yang mana penelitian-penelitian didalamnya memiliki langkah yang tidak homogen, oleh sebab itu penulis tidak menggunakan meta-analysis.

\section{HASIL DAN PEMBAHASAN}

Pencarian data artikel secara gabungan dengan memasukan kriteria tahun publikasi antara tahun 2014 hingga tahun 2019, keseluruhan artikel yang terkumpul dari 5 sumber besar sebanyak 152 artikel yang terindeks menggunakan kata kunci dan berbagai kriteria yang telah ditentukan sebelumnya. Artikel yang dikeluarkan dalam proses pencarian adalah tidak berfokus pada penyakit kronis, tidak disajikan dengan full text dan tidak menggunakan bahasa inggris. Pemilahan artikel yang dinilai ganda juga tidak lepas dari seleksi ini, dimana ada 38 artikel yang ganda (dengan judul yang sama) dari berbagai sumber. Total responden pada studi adalah 385 orang, dengan subjek jenis kelamin perempuaan sebanyak 238 (62\%) dan laki-laki sebanyak 147 (38\%) orang. Pasien dengan berbagai macam penyakit kronis antara lain Diabetes, Hipertensi, Chronic low back pain, Gestational Diabetes, Breast Cancer, CKD (on Hemodialysis), Chronic Atrial Fibrillation. Studi dalam literature review ini menggunakan berbagai intervensi yakni Acceptance and Commitment Therapy, Peer Group Education, edukasi berbasis Health Belief Model Meditasi Yoga Sahaja, Program Based on-Self care, Aerobic Physical Rehabilitation dan Hipnoterapi. Hasil pada kelompok intervensi pada setiap artikel dalam studi ini menunjukkan peningkatan kualitas hidup, semua artikel juga menunjukkan signifikansi antara pre dan post test. 
Alat ukur yang digunakan dalam yang diulas dalam studi ini antara lain: 1) WHOQOL (World Health Organization Quality of Life), MPQ (McGill Pain Questionnaire Modified) dalam artikel yang berjudul Effectiveness of Acceptance and Commitment-Based Therapy (ACT Rehab) on Quality of Life, Saverity and Duration of Pain: in Women With Chronic Low Back Pain didapatkan peningkatan setiap komponen kualitas hidup pada kelompok intervensi dibandingkan dengan kelompok kontrol pada dengan nilai $(p<0.001)$ meskipun pada durasi dan kualitas nyeri tidak begitu signifikan $(p<0.23)$ (Seyedeh Maryam, 2018). 2) DQOL (the Diabetes Quality of Life) dalam artikel yang berjudul Effect of Peer Group Education on the Quality of Life of Elderly Individuals with Diabetes: a Randomized Clinical Trial didapatkan peningkatan kualitas hidup pada lansia dengan diabetes setelah dilakukan edukasi peer group dengan nilai signifikansi $(p=0.001$ ) (Maryam Ghasemi, 2018). 3) Pada artikel yang ketiga menggunakan alat ukur berupa kuesioner hasil dari pengembangan peneliti sendiri yang mengacu pada nilai-nilai Health Belief Model didapatkan hasil bahwa terjadi peningkatan pada setiap komponen HBM dengan signifikansi ( $p<0.001$ ) (Reza Tavakkoli, 2018). 4) SF-36 (Short Form-36) dalam artikel yang berjudul The effects of an Interventional Program Based on Self-care Model on Health Related Quality of Life Outcomes in Hemodialysis Patient didapatkan bahwa intervensi Program Based on Self-care terbukti efektif meningkatkan kualitas hidup pada pasien CKD yang sedang menjalani hemodialisis dengan nilai signifikansi ( $p<0.001$ ) (Mohammadkarim Bahadori, 2017). 5) SF-36 (Short Form-36) dalam studi yang berjudul The Effect of Aerobic Physical Rehabilitation On The Quality of Life in Patients with Chronic Atrial Fibrillation : Randomized Controlled Clinical Trial Study terdapat peningkatan kualitas hidup pada kelompok intervensi dengan signifikansi nilai ( $p<0.0050)$ (Zohreh, 2018). 6) WHOQOLBREEF WHOQOL-SRPB dalam artikel yang berjudul Effect of Sahaja Yoga Meditation on Quality of Life, Anxiety, and Blood Pressure Control ditemukan adanya penurunan kecemasan dan tekanan darah yang signifikan antara grup intervensi dengan grup kontrol pada post test dengan nilai $(p<0.001)$ sedangkan pada kualitas hidup terjadi peningkatan ( $p<0.001$ ) (Sheng-Chia Chung, 2017). 7) EORTC QLQ-C3O (the European Organization for Research and Treatment of Cancer Quality of Life Questionnaire) dalam studi yang berjudul The effect of Hypnotherapy on The quality of life in Women with Breast Cancer didapatkan hasil peningkatan yang signifikan antara kualitas hidup wanita dengan kanker payudara pada kelompok kontrol dan intervensi setelah dilakukan intervensi hipnoterapi dengan nilai signifikansi ( $p=0.0003$ ) (Arnoldo Téllez, 2017).

\section{PEMBAHASAN}

Bardasarkan hasil analisis beberapa literatur didapatkan bahwa beberapa intervensi berikut dapat dijadikan sebagai bahan referensi sebagai upaya peningkatan kualitas hidup pada pasien dengan berbagai penyakit kronis, diantaranya: Acceptance and Commitment Teraphy (ACT), Peer Support Group (Edukasi), Edukasi berbasis Health Belief Model (Edukasi), Program Berbasis Self-care, Aerobik rehabilitas fisik, Meditasi Yoga Sahaja dan Hipnoterapi.

Acceptance and Coomitment Teraphy : Acceptance and Commitment Terapphy merupakan sebuah terapi kognitif yang bertujuan meningkatkan fleksibilitas aspek psikologi seseorang dengan berorientasi pada nilai-nilai penerimaan, kesadaran dan sebuah komitmen terhadap diri sendiri dengan setiap apapun pengalaman dialami. ACT memiliki 6 (enam) sasaran yakni; 1 ) menjadi guidance bagi klien dalam aplikasi terhadap pengalaman langsung dengan respon yang efektif. 2) menjadi controler bagi klien dalam memaknai setiap permasalahan yang dialami. 3) membantu klien agar menanamkan penerimaan dan menyadari sepenuhnya setiap permasalahan yang dialami merupakan bagian untuk mencapai kesejahteraan. 4) membantu klien dalam menanamkan kesadaran bawa setiap peneriamaan yang terbentuk merupakan buah dari apa yang diucapkan. 5) membantu klien dalam menanamkan kesadaran bahwa diri sendirilah yang bisa melakukan penerimaan dan berkomitmen untuk konsisten melakukan setiap tindakan yang benar dan berani menghadapi setiap permasalahan. 6) membantu klien dalam memaknai dan melakukan analisis terhadap nilai-nilai yang ada saat ini sebagai landasan dalam pengambilan keputusan dalam hidupnya (Hayes, Stefen, 2006) dan (Strosahl, 2002). Metode intervensi ACT dilaksanakan dalam 6 sesi yakni sesi Acceptance : klien 
dibantu dalam penerimaan terhadap setiap apapun yang terjadi, baik itu hal yang tidak diinginkan, kesedihan, mengharukan dan lain sebagainya. Pada sesi ini klien diminta untuk menyadari dengan penuh bahwa setiap masalah adalah bagian dari kehidupan dan harus bisa hidup dengan setiap masalah tersebut. Cognitive defusion: Klien dilatih sebuah teknik mereduksi setiap penolakan pada setiap pengalaman yang dianggap tidak mengenakan seperti; perasaan malu, sedih, merasa dihina dan lain sebagainya. Being present : Pada sesi ini klien akan dibantu dalam menemukan pengalaman berharga, tujuan hidup yang terarah, fleksibel dan konsisten dalam melakukan tujuan tersebut sesuai dengan nilai yang dianutnya. Klien akan dibimbing dalam menemukan hidup yang lebih bermakna dan berharga. Self as a contex : Klien dibantu dalam memaknai dirinya dengan tidak menghakimi benar atau salahnya. Klien akan diminta untuk fokus pada tujuan dengan cara latihan fikiran dan pengalaman. Values : Klien dibimbing dalam menentukan nilai-nilai kehidupan dan mampu mengambil keputusan terhadap setiap tindakan yang sesuai dengan tujuan hidupnya. Commited action : Klien diminta untuk berjanji dan berkomitmen akan konsisten terhadap setiap langkah yang dilakukan untuk mencapai tujuan hidup yang lebih berharga (Endang, 2012).

Educational Based Peer Support Group : Edukasi berbasis Peer Support Group merupakan jenis terapi kognitif yang mengedepankan dukungan antar teman sebaya yang sama-sama memiliki persamaan karakteristik antara satu orang dengan yang lainnya (Societies, 2009). Hasil penelitian lain yang menunjukkan keberhasilan Peer educatioan di mana model telah berhasil merubah perilaku warga binaan agar memiliki kesadaran untuk memeriksakan sputum sebagai skrining TBC pada masyarakat binaan (Akbar, 2018) dan pemeliharaan kesehatan termasuk latihan manajemen diet dan istirahat pada pasien Diabetes Melitus'(Maryam Ghasemi, 2018). Metode Peer education pada studi sebagai berikut: grup kontrol mendapatkan pelatihan dari peneliti, sedangkan grup intervensi diberikan edukasi dari teman sebayanya. Materi edukasi yang disajikan mengenai perawatan diri, olahraga, manajemen diet, perawatan kulit dan membahas elemen terkait quality of life serta kekhawatiran secara umum terjadi terkait penyakit diabetes melitus. Materi disajikan dalam bentuk ceramah tanyajawab. Kedua grup mendapatkan 8 sesi pelatihan, setiap sesi dilakukan selama 30-45 menit. Hasil studi ini menunjukan bahwa Peer education dengan signifikan lebih baik meningkatkan kualitas hidup dari pada pelatihan yang didapatkan dari peneliti (yang didapatkan oleh kelompok kontrol).

Educational Intervention Based on the Health Belief Model (HBM) merupakan model edukasi yang berorientasi pada penjelasan-penjelasan serta prediksi prediksi kesehatan yang difokuskan pada sikap dan nilai keyakinan seseorang (Rosenstock \& Ph, 1960). Edukasi berbasis Health Belief Model telah banyak digunakan pada bidang keperawatan dan berhasil dalam meningkatkan kualitas hidup pada pasien dengan berbagai penyakit kronis. (Lilis Lismayanti, 2017) (Reza Tavakkoli, 2018) (Shabibi et al, 2017). Metode yang digunakan dalam studi ini; pada kelompok intervensi diberikan materi edukasi berbasis Health Belief Model sebanyak 6 sesi di mana setiap sesinya diberikan selama 45 menit dengan peserta sebanyak 10 orang setiap sesinya dan dilakukan setiap minggu selama 2 bulan. Responden dalam studi ini adalah wanita hamil dengan diabetes yang sedang menjalani terapi insulin dengan ditemani oleh anggota keluarga yang paling berperan. Hasil studi ini menunjukkan adanya pengaruh yang signifikan terhadap perbandingan nilai antara grup kontrol dengan grup intervensi pada pre-test dan post-test dengan signifikansi $(p<0.001)$ dengan kata lain bahwa penerapan model edukasi dengan Health Belief Model efekif dalam meningkatkan kualitas hidup pada wanita hamil dengan diabetes (Reza Tavakkoli, 2018).

Program based on self-care model diartikan sebagai sebuah intervensi edukasi berbasis model selfcare merupakan program edukasi yang berorientasi pada pemberdayaan klien terhadap perawatan diri yang dilakukan secara mandiri. Menurut martha Raile (2013) Self care memiliki tiga pilar aplikatif yakni teori perawatan diri (self care theory), agen perawatan diri (self care agency) dan kebutuhan perawatan diri terapeutik (therapeutic self care demands). Edukasi berbasis self-care efektif dalam meningkatkan kualitas hidup dengan kepatuhan terhadap progaram pengobatan dengan berbagai 
penyakit kronis (Mohammadkarim Bahadori, 2017) (Nosratollah, 2018). Metode edukasi berbasis selfcare dalam studi ini terdiri dari 4 tahapan yakni (1) Motivating, (2) Preparing, (3) Involving (4) Evaluating. Selama tahap Motivating, klien menyadari penyakit serta capaian kemandiriannya dengan menghadiri sesi training. Pada tahap Preparing klien menentukan tujuan, jadwal dan tabel waktu program edukasi berbasis partnership dan penentuan alur edukasi. Tahap Involving pertemuan diadakan. Evaluasi terhadap capaian tujuan di lakukan pada tahap Evaluating. Materi edukasi yang telah disusun didapatkan dari karya ilmiah yang telah valid diberikan kepada klien tentang : latihan, istirahat tidur, nutrisi, stres, peralatan hemodialisis, metode hemodialisis, pencegahan terhadap gatalgatal efek hemodialisis dan psikologi secara terjadwal. Edukasi diberikan sebanyak 8 sesi selama 120 menit dan berlangsung dalam 2 bulan. Pada topik latihan seorang fisiotrapis dan peneliti memberikan training secara teori dan praktik kepada semua responden, sesi berikutnya peneliti melakukan evaluasi terkait pertanyaan dan penjelasan ulang kepada semua responden. Hasil yang didapat dari studi ini menunjukkan hasil yang positif terhadap peningkatan kualitas hidup pada semua responden dengan $(p<0.001)$ pada pre test dan post test (Mohammadkarim Bahadori, 2017) dengan kata lain bahwa intervensi edukasi berbasis self-care efektif meningkatkan kualitas hidup pada pasien dengan gagal ginjal kronis yang menjalani terapi hemodialisis.

Intervensi aerobic merupakan serangkaian latihan fisik yang diiringi dengan atau tanpa irama musik sebagai upaya meningkatkan efisiensi oksigen pada jaringan tubuh. Aerobic dapat dilakukan dengan cara senam, cycling, treadmill dan gerakan fisik lainya (Lippincott Williams \& Wilkins, 2013). Latihan aerobic yang dilakukan dengan teratur mampu memperbaiki mekanisme kerja jantung dan paru-paru (Harsh Patel, 2017) (Zohreh, 2018). Metode aerobic yang dilakukan dalam studi ini dengan cara treadmill yang dilakukan sebanyak 2 kali dalam seminggu dengan intensitas ringan sampai sedang sesuai dengan rekomendasi dokter kardiologi, setiap sesi berlangsung selama 60 menit yang terdiri dari 10 menit pemanasan, 40 menit gerakan treadmill dan 10 menit berikutnya adalah pendinginan. Pada periode 4 minggu pertama program reahabilitasi berisi latihan dengan intensitas $40-50 \%$ dari maximum oxygen consumption atau heart rate dan maximum metabolic equivalent (MET) 3.0-5.9. Pada periode 4 minggu kedua program telah diselesaikan dengan intensitas ditingkatkan menjadi 70$80 \%$ dari maximum oxygen consumption atau heart rate dengan maximum metabolic equivalent (MET) sebesar 8.9. Kelompok kontrol diimplementasikan dengan penjelasan tentang rehabilitasi fisik secara verbal dan lebih sering mendengarkan pertanyaan-pertanyaan responden tentang edukasi dan latihan dengan media pamflet. Hasil dari studi ini menunjukkan bahwa ada peningkatan yang signifikan antara pre-test dan post-test pada kelompok intervensi. Dengan nilai $(p<0.050)$.

Yoga merupakan sebuah kegiatan yang dilakukan dengan hati yang tenang, namun penuh konsentrasi tinggi dengan memvisualisasikan penyatuan tubuh dan pikiran dan dilakukan dengan kesadaran (Raghavendra, 2017). Meditasi Yoga Sahaja adalah meditasi dengan membuat seseorang berkonsentrasi tinggi dengan mengatur nafas, membersihkan fikiran dengan pose tubuh tertentu yang dilakukan berdasarkan konteks rekognisi realistis dari keadaan psikologis yang aktual (Chidananda, 1984). Meditasi Yoga Sahaja telah banyak digunakan sebagai intervensi yang mampu mempengaruhi pikiran bawah sadar dan menjadikan hidup lebih, sehat, produktif dan berenergi (Rajeev, 2010) (Putu Wirmayani, 2017). Metode meditasi yoga sahaja dalam studi ini dilakukan dengan cara aplikasi praktek pembersihan dengan meditasi sehari-sehari. Pengaruh terapeutik akan dirasakan pada kondisi pikiran yang hening dimana sesorang dengan nyaman melakukan introspeksi diri, mengatasi dan menyelesaikan setiap tekanan oleh pikiran negatif, emosi atau disebabkan oleh perilaku buruk. Responden yang susah berkonsentrasi dalam mencapai pembersihan (keheningan) dapat melakukan latihan sederhana sambil merendamkan kaki ke dalam wadah berisi air garam, sementara pada kelompok kontrol responden tidak diberikan intervensi ini, responden diberikan dengan pengobatan medis di rumah sakit (Sheng-Chia Chung, 2017). Hasil studi ini menunjukkan hasil yang positif terhadap peningkatan kualitas hidup dan penurunan ansietas. WHOQOL-SRPB, WHOQOL-BREF dan CAS menunjukkan nilai signifikansi pada kelompok intervensi pre dan post-test $(p<0.001)$. 
Hipnoterapi; hipnoterapi adalah sebuah terapi komplementer yang menggunakan tekhnik hipnosis sebagai metode penyembuhan (Dadi, 2019) (Kendrick, 2010). Hipnoterapi merupakan gabungan antara hipnosis dan intervensi terapeutik (Dadi, 2019). Metode hipnoterapi adalah dengan cara memasukkan sugesti positif ke dalam pikiran bawah sadar klien ketika kondisinya pada titik trance. Hipnoterapis akan menggunakan kata-kata tertentu sebagai pemberi efek terapeutik kepada klien, oleh sebab itu tingkat keberhasilan hipnoterapi sangat ditentukan oleh komunikasi yang dilakukan oleh therapis. Hipnoterapi telah banyak digunakan sebagai terapi komplementer dan berhasil menyembuhkan gangguan fisik, psikologis dan mengubah perilaku (Arnoldo Téllez, 2017) (Dadi, 2019) (Kendrick, 2010). Hipnoterapi termasuk intervensi non farmakologis dengan ketegori terapi kognitif dengan sasaran utamanya meliputi korteks serebri, bagian berpikir pada otak, sistem limbik serta sistem saraf simpatis dan parasimpatis (Wu, 2012). Pemberian hipnoterapi dalam studi ini dilakukan selama 6 bulan dalam waktu 90 menit sekali pemberian dengan total sesi sebanyak 24 sesi hipnoterapi, yang dibagi 2 fase. Fase pertama terdiri dari 12 sesi intensif dengan frekuensi 3 sesi setap minggu. Fase kedua termasuk 12 sesi berikutnya dengan frekuensi 1 sesi setiap 2 minggu.

Partisipan dalam studi ini berjumlah 40 orang pasien kanker payudara dengan pembagian 20 orang pada kelompok kontrol dan 20 kelompok intervensi. Pada kelompok intervensi partisipan diminta menanda tangani persetujuan untuk diberikan intervensi hipnoterapi dan selanjutnya diberikan hipnoterapi, sementara partisipan pada kelompok kontrol hanya menandatangani surat kesediaan sebagai responden dalam kelompok kontrol selanjutnya hanya mendapat terapi pengobatan rumah sakit. Hasil dari studi ini menunjukkan bahwa efek hipnoterapi berefek positif pada fungsi kognitif serta peningkatan yang signifikan pada setiap aspek kualitas hidup. Hipnoterapi dapat memberikan manfaat positif pada wanita dengan kanker yang menjalani kemoterapi (Arnoldo Téllez, 2017)

\section{SIMPULAN DAN SARAN}

Kesimpulan dari studi literature review ini bahwa Acceptance and commitment therapy (ACT), edukasi bebasis peer group, edukasi berbasis health belief model, edukasi self-care model, aerobik, meditasi yoga dan hipnoterapi merupakan berbagai model terapi kognitif yang mampu meningkatkan kualitas hidup dan dapat digunakan pada pasien dengan berbagai penyakit kronis. Berbagai model terapi kognitif yang telah dijelaskan sebelumnya dapat aplikasikan sebagai upaya peningkatan kualitas hidup dan mengurangi risiko negatif pada aspek biologis, psikologis, sosial, dan spiritual pada pasien dengan penyakit kronis yang menjalani pengobatan dilingkungan medis. Analisis hasil dari beberapa studi ditemukan bahwa terapi fisik, psikologis dan perilaku dapat direkomendasikan sebagai terapi non farmakologis untuk meningkatkan kualitas hidup pada pasien dengan penyakit kronis.

Kualitas hidup memiliki cakupan yang luas, tidak hanya terbatasi dengan pemenuhan kebutuhan fisiologis tetapi juga pada aspek psikologis, sosial, spiritual. Menjawab permasalahan pada kualitas hidup tentunya tidak bisa hanya bisa dilakukan dengan pengobatan dengan obat-obatan medis (cure) saja tetapi juga harus mempertimbangkan dari segi perhatian (caring) juga. Literature review ini harapannya bisa menjadi bahan referensi bagi akademisi maupun klinisi yang bisa diterapkan kepada pasien dengan penyakit kronis sebagai upaya peningkatan kualitas hidup.

\section{DAFTAR PUSTAKA}

Akbar, A. (2018). Pengaruh Peer Education Terhadap Niat Warga Binaan Pemasyarakatan Laki-laki dalam Melakukan Pemeriksaan Dahak TBC. Inversitas Diponegoro.

Arnoldo Téllez. (2017). The Effect of Hypnotherapy on the Quality of ILife in Women with Breast Cancer. Russian Psychological Society, 10, 228-240. https://doi.org/10.11621/pir.2017.0216

Chidananda. (1984). The Philosophy, Psychology and Practice of Yoga. India: The Divine Life Society. 
Dadi, H. (2019). Intervensi untuk Mengatasi Mual Antisipatori pada Pasien Kanker yang Menjalani Kemoterapi. Jurnal SMART Keperawatan, 6(1), 65-71. https://doi.org/DOI: 10.34310/jskp.v6i1.239

Endang, W. (2012). Pengaruh Acceptance and Commitment Teraphy Terhadap Respon Ketidakberdayaan Klien Gagal Ginjal Kronik di RSUP Fatmawati Jakarta. Universitas Indonesia.

Harsh Patel. (2017). Aerobic vs anaerobic exercise training effects on the cardiovascular system. World Journal of Cardiology, 2, 134-138. https://doi.org/10.4330/wjc.v9.i2.134

Hayes, Stefen, J. (2006). ACT: Model, Proceses and Outcomes. Journal of Behaviour Research and Teraphy, 44, 1-44.

Kemenkes RI. (2016). Pedoman Umum Program Indonesia Sehat Dengan Pendekatan Keluarga. (Pusat Analisis Determinan Kesehatan Kementerian Kesehatan, Ed.). Jakarta: Kementerian Kesehatan RI.

Kendrick. (2010). Exhaled Carbon Monoxide Devices in Smoking Cessation : Chemotherapy. Oncology, 59(2), 100-104. https://doi.org/10.1159/000012144

Kousoula Gerasimoula, et al. (2015). Quality of Life in Hemodialysis Patients. Materia Socio Medika, 5, 305-309. https://doi.org/10.5455/msm.2015.27.305-309

Lilis Lismayanti, N. P. S. (2017). Pengaruh Edukasi Health Belief Model Terhadap Kualitas Hidup Penderita Tuberculosis Di PKM Tamansari Kota Tasikmalaya. Researchgate, (May 2018).

Lippincott Williams \& Wilkins. (2013). ACSM's guidelines for exercise testing and prescription. American College of Sports Medicine.

Lubkin \& Larsen, P. (2006). Chronic illness: Impact and interventions (6th ed.). USA: Jones and Bartlett Publisher Inc.

Martha Raile, A. (2017). Pakar Teori Keperawatan (8th ed.). 3 Killiney Road, Singapore: Elsevier.

Maryam Ghasemi. (2018). Effect of Peer Group Education on the Quality of Life of Elderly Individuals with Diabetes: A Randomized Clinical Trial. Iranian Journal of Nursing and Midwifery Research, 24, 44-49. https://doi.org/10.4103/ijnmr.IJNMR_39_17

Mohammadkarim Bahadori. (2017). The effects of an interventional program based on self-care model on health-related quality of life outcomes in hemodialysis patients. Journal of Education and Health Promotion, 3, 1-8. https://doi.org/10.4103/2277-9531.145899

Nosratollah, M. (2018). The Effect of Self- Care Education Based on Orem's Model on Self-Efficacy of Patients with BetaThalassemia Major. La Prensa Medica Argentina, 104, 4. https://doi.org/10.4172/Ipma.100029

Putu Wirmayani. (2017). Pengaruh Yoga Terhadap Konsentrasi Belajar Anak SD Negeri di Denpasar. Jurnal Psikologi Udayana, 4(2), 460-473.

Raghavendra. (2017). Effects of an Integrated Yoga Programme on Chemotherapy Induced Nausea 
and Emesis in Breast Cancer Patients. European Journal of Cancer Care, 16, 462-474. https://doi.org//10.1111/j.1365- 2354.2006.00739.x

Rahma, D. (2015). Hubungan Motivasi, Harapan dan Dukungan Petugas Kesehatan Terhadap Kepatuhan Pasien Gagal Ginjal Kronik Untuk Menjalani Hemodialisis. JOM, 2, 1362-1371. Retrieved from https://media.neliti.com/media/publications/184149-ID-hubungan-motivasiharapan-dan-dukungan-p.pdf

Rajeev, C. (2010). Effect of Sahaja Yoga Meditation on the Life Style of University Students. Banaras Hindu University.

Reza Tavakkoli. (2018). Study the Effect of Educational Intervention Based on the Health Belief Model (HBM) On Quality of Life Among Women with Gestational Diabetes. Journal of Research in Medical and Dental Sciences, 6(2), 245-252. https://doi.org/10.5455/jrmds.20186238

Rosenstock, I. M., \& Ph, D. (1960). Historical Origins of the Health Belief Model, 2(4).

Seyedeh Maryam. (2018). Effectiveness of Acceptance and Commitment-Based Therapy (ACT Rehab) on Quality of Life, Severity and Duration of Pain; in Women With Chronic Low Back Pain. Iranian Rehabilitation Journal, 16, 103-116. https://doi.org/10.29252/NRIP.IRJ.16.1.103

Shabibi, P., Sadegh, M., Zavareh, A., Sayehmiri, K., Qorbani, M., Rastegarimehr, B., ... Management, H. (2017). Effect of educational intervention based on the Health Belief Model on Promoting selfcare behaviors of type-2 diabetes patients. Electronic Physician, (December), 5960-5968. Retrieved from http://dx.doi.org/10.19082/5960

Sheila Perry, et al. (2007). Quality of Life Assessment in Women with Breast Cancer: Benefits, Acceptability and Utilization. Health and Quality of Life Outcomes, 5, 24. https://doi.org/10.1186/1477-7525-5-24

Sheng-Chia Chung. (2017). Effect of Sahaja Yoga Meditation on Quality of Life, Anxiety, and Blood Pressure Control. THE JOURNAL OF ALTERNATIVE AND COMPLEMENTARY MEDICINE, 18, 589596. https://doi.org/10.1089/acm.2011.0038

Societies, I. F. of R. C. and R. C. (2009). Standards for HIV peer education programmes.

Sohaib T. Khatib, et al. (2018). Quality of Life in Hemodialysis Diabetic Patients: a Multicenter Crosssectional Study from Palestine. BMC Nephrology, 19, 10.1186/s12882-018-0849-x. https://doi.org/10.1186/s12882-018-0849-x

Strosahl, K. (2002). Acceptance and Commitment Teraphy (2nd ed.). New York: Elsevier.

Stuart. (2013). Principles and Practice of Psychiatric Nursing (10th ed.). St. louis, Missouri: Mosby Elsevier.

Vani Rahmasari. (2018). Manajemen Terapi Demam Tifoid: Kajian Terapi Farmakologis dan Non farmakologis. Farmaka, 16(1), 184-195.

Wu. (2012). Psychoneuroimmunology Part II Mind-Body Intervention. BMJ Journals, 2(2), 44-46.

Zohreh. (2018). The Effect of Aerobic Physical Rehabilitation on the Quality of Life in Patients with 
Chronic Atrial Fibrillation; a Randomized Controlled Clinical Trial Study. Arya Atheroschler, 15, 1-8. https://doi.org/http://dx.doi.org/10.22122/arya.v15i1.1705 